\author{
Yevheniia Yu. Nikiforova \\ ORCID ID: 0000-0001-6249-9781 \\ Tetiana O. Biletska \\ ORCID ID: 0000-0002-5376-4819 \\ Scopus ID: 57219281617 \\ Elizaveta A. Galitska \\ ORCID ID: 0000-0002-0859-1322
}

\title{
INTERACTION OF NOMINATION TYPES IN THE SPHERE OF PERFUME AND COSMETIC NAMING
}

\begin{abstract}
This article deals with the aspect of naming the perfume and make-up goods. Special attention is given to the specifications of goods names in the sphere of interacting with the nomination types. Perfume and cosmetic names are created involving primary and secondary types of nomination and simultaneously describing corresponding features, qualities and individual characteristics of these goods. In the case of a primary nomination, a motivation feature is designated with a word that has the basic meaning containing the indication of the motivation feature. Name meaning correlates with the reality which is denotated and causes the direct reflection of object features. In the case of a secondary nomination, the indication of the distinguished feature is realized through comparison or confrontation with another object having the same features. Perfume and cosmetic naming is realised within the frame of the naming complex. This complex contains two naming components: the individual name and the goods name. Functioning within one common naming complex, these two names influence each other. Perfume goods creating aromatic, fragrant effect have olfactory feature as their basic characteristics. It means that combinations of smell, scent, aroma, fragrance concentrated in aromatic solutions of different substances correspond to the essential requirements to aromatic liquid goods. The goods in the branch of make-up creating visual effect have colour and colouring as their basic characteristics. The process of secondary naming, when perfume and make-up goods obtain individual names, consists of four basic stages: (1) archseme fading; (2) seme displacement; (3) potential seme actualisation; (4) occasional seme formation. At the very end of these transformations, the individual name is turned into a semantic derivative, the product of a secondary nomination. The most frequent semantic derivation for creating perfume and make-up names is metaphorical transferring that is based on the feature resemblance
\end{abstract}


of two objects which are not connected with reality. The semantic structure of individual names of naming frames is the reflection of the relation existing between objects of extralinguistic reality. It also reflects the results of the cognitive activity of a nominator. The process of the name functional adaptation takes place when the individual names create passing from the primary to the secondary nomination.

Keywords: cosmetics, nominative complex, nomination, perfume, seme, semantic derivative

Information about the authors: Nikiforova Yevheniia Yuriivna PhD in English Philology, Assistant Professor, Assistant Professor at the Department of English Philology and Intercultural Communication; Institute of Philology; Taras Shevchenko National University of Kyiv.

Biletska Tetiana Oleksandrivna - PhD in English Philology, Assistant Professor, Assistant Professor at the Department of English Philology and Intercultural Communication; Institute of Philology; Taras Shevchenko National University of Kyiv.

Galitska Elizaveta Anatoliivna - PhD in English Philology, Teacher of the English and German languages; Kyiv Gymnasium №86 "Consul".

E-mail: elt.nikiforova@gmail.com; t.biletska@knu.ua; Liza-g@ukr.net

Нікіфорова $\boldsymbol{C .}$.

ORCID ID: 0000-0001-6249-9781

Білецька Т. $О$.

ORCID ID: 0000-0002-5376-4819

Scopus ID: 57219281617

Галицька $\boldsymbol{C}$. $A$.

ORCID ID: 0000-0002-0859-1322

\section{ВЗАСМОДІЯ ТИПІВ НОМІНАЦІЇ У СФЕРІ ПАРФУМЕРНО-КОСМЕТИЧНОГО НЕЙМІНГУ}

Анотація. У статті розглянуто аспект номінації парфумернокосметичних товарів. Особливу увагу приділено специфікації товарних назв із огляду на взаємодію типів номінації. Парфумерно-косметичні назви утворені шляхом залучення первинної $i$ вторинної номінації з одночасним описом відповідних товарних властивостей, якісних та індивідуальних характеристик. $У$ випадку первинної номіначї мотивачійна ознака визначається словом, що має базове значення, яке містить вказівку на мотивачійну ознаку. Значення назви співвідноситься $з$ реальністю, що позначається $i$ спричиняе безпосереднє віддзеркалення властивостей номінованого об'єкта. У випадку вторинної номіначії вказівка на визначені властивості здійснюється шляхом порівняння або зіставлення з іншим об'єктом, 
щуо має схожі властивості. Парфумерно-косметична номінація відбувається у межах номінативного комплексу, щуо містить два номінативні компоненти: індивідуальну назву $i$ товарну назву. Функціонуючи разом у межах спільного номінативного комплексу, ичі дві назви впливають одна на одну. Парфумерні товари, створюючи ароматичний, одоративний ефект, мають ольфакторну властивість, щзо виступає як базова. Це означає, щчо комбінація ароматів, запахів, пахощтів, які сконцентровані в ароматичних розчинах різних субстанцій, відповідають необхідним вимогам ароматичної рідкої товарної продукції. Товари, щуо належать до косметичного відгалуження, створюючи візуальний, оптичний ефект, мають колір та забарвлення як основні характеристики. Процес вторинної номінації, коли парфумерно-косметичні товари отримують індивідуальні назви, складається з чотирьох стадій: (1) приглушення архісеми; (2) зсув семи; (3) актуалізація потениійної семи; (4) утворення оказіональної семи. У самому кінці иъього ланцюга трансформацій індивідуальна назва перетворюється на семантичний дериват, продукт вторинної номінації. Найчастотнішою семантичною деривачією при утворенні парфумерно-косметичних назв є метафоричне перенесення, що трунтується на схожості двох об'єктів не пов'язаних із реальністю. Семантична структура індивідуальних назв номінативних фреймів є віддзеркаленням зв'язків, щзо існують між об'єктами екстралінгвістичної дійсності. Семантична структура також відображає результати номінативної активності номінатора. Процес функціонального прилаштування назви відбувається, коли створюються індивідуальні назви, переходячи з первинної до вторинної номінації.

Ключові слова: косметика, номінативний комплекс, номінація, парфуми, сема, семантичний дериват.

Інформація про авторів: Нікіфорова Свгенія Юрївна кандидат філологічних наук; асистент кафедри англійської філології та міжкультурної комунікацїі; Інститут філологї; Київський національний університет імені Тараса Шевченка.

Білецька Тетяна Олександрівна - кандидат філологічних наук; асистент кафедри англійської філологї та міжкультурної комунікаціӥ; Інститут філологї; Київський національний університет імені Тараса Шевченка.

Галицька Слизавета Анатоліївна - кандидат філологічних наук, вчителька англійської та німецьккӧ̈ мов; Киїська гімназія № 86 "Консул".

Електронна адреса: elt.nikiforova@gmail.com; t.biletska@knu.ua; Liza-g@ukr.net 
Никифорова Е. Ю.

ORCID ID: 0000-0001-6249-9781

Белецкая Т. $A$.

ORCID ID: 0000-0002-5376-4819

Scopus ID: 57219281617

Галицкая Е. $A$.

ORCID ID: 0000-0002-0859-1322

\section{ВЗАИМОДЕЙСТВИЕ ТИПОВ НОМИНАЦИИ В СФЕРЕ ПАРФЮМЕРНО-КОСМЕТИЧЕСКОГО НЕЙМИНГА}

Аннотация. Статья рассматривает аспект номинации парфюмерно-косметических товаров. Особое внимание уделено спеиифике товарных названий с учетом взаимодействия типов номиначии. Парфюмерно-косметические названия образованы путем использования первичной и вторичной номинации с одновременным написанием соответствующих товарных свойств, количественных $и$ индивидуальных характеристик. В случае первичной номинации мотивачионный признак определяется словом, имеющим базовое значение, которое содержит указание на мотивационный признак. Значение слова соотносится с реальностью, которая обозначается $и$ получает непосредственное отображение свойств номинированного объекта. В случае вторичной номинации указание на определенные свойства осуществляется путем сравнения или противопоставления с другим объектом, имеющим такие же свойства. Парфюмернокосметическая номинация происходит в пределах номинативного комплекса, содержащего два номинативных компонента: индивидуальное название $и$ товарное название. Функиионируя совместно в пределах общего номинативного комплекса, эти два названия влияют друг на друга. Парфюмерные товары, образуя ароматический эффект, обладают ольфакторным свойством, которое выступает как базовое. Это означает, что комбинация ароматов, запахов, благовоний, которые сконцентрированы $в$ ароматных растворах разных жидких субстанций, отвечают необходимым требованиям ароматной, жидкой товарной продукиии. Товары, принадлежащие к косметическому ответвлению, образуя визуальный, оптический эффект, обладают иветом и окраской как основными характеристиками. Прочесс вторичной номинации, когда парфюмерно-косметические товары получают индивидуальные названия, включает четыре стадии: (1) приглушение архисемы; (2) смещение семы; (3) актуализация потенциальной семы; (4) образование окказиональной семьл. В самом конце этой цепи 
Актуальні проблеми української лінгвістики: теорія і практика

трансформаций индивидуальное название превращается ${ }_{6}$ семантический дериват, продукт вторичной номинации. Самой частотной семантической деривацией при образовании парфюмернокосметических названий является метафорический перенос, который основывается на схожести двух объектов, не связанных с реальностью. Семантическая структура индивидуальных названий номинативных фреймов является отражением связей, существующих между объектами экстралингвистической реальности. Эта структура также отражает результать когнитивной деятельности номинатора. Процесс функииональной адаптации названия происходит, когда формируются индивидуальные названия, переходя с первичной во вторичную номинацию.

Ключевые слова: косметика, номинативный комплекс, номинация, духи, сема, семантический дериват.

Информация про авторов: Никифорова Евгения Юрьевна кандидат филологических наук, ассистент кафедры английской филологии и межкультурной коммуникации; Институт филологии; Киевский национальный университет имени Тараса Шевченка.

Белеикая Татьяна Александровна - кандидат филологических наук, ассистент кафедры английской филологии и межкультурной коммуникации; Институт филологии; Киевский национальный университет имени Тараса Шевченка.

Галицкая Елизавета Анатольевна - кандидат филологических наук, учитель английского и немеикого языков; Киевская гимназия №86 "Консул".

Электронный адрес: elt.nikiforova@gmail.com; t.biletska@knu.ua; Liza-g@ukr.net

Language development is tightly connected with the cognitive activity of mankind and causes the necessity of naming not only the results of mental activity but also the results of productive activity when new objects, materials, substances and goods are manufactured. It stimulates creating the names which describe quantitative and qualitative goods parameters, indicate specific properties and their recognitive features. One of the oldest types of human activity was trade which included goods production and their further selling. This type of human activity and its results needed corresponding names as they were reflected mostly in goods terminology [8].

The purpose of the article is to find out the structure of perfume and cosmetic names and the processes of their inner 
interaction, revealing the types of nomination used for naming corresponding classes and subclasses of these goods, tracing out the ways of interacting the types of nomination, distinguishing the stages and steps of forming and creating the naming units for perfume and cosmetic goods. The topicality of the research is connected with common tendencies of modern linguistic research that are connected with reflecting in the language the processes of human activity, especially, creating names of products and consumer goods. The necessity of investigating the goods naming caused the polyaspective research of structural and semantic levels of perfume and cosmetic goods in particular. The scientific novelty of the research arises from the necessity of providing the first systematic and steady investigation of naming processes within the naming complexes in the aspect of inner interacting the types of nomination. The object of the research is the set of naming complexes reflecting corresponding perfumes and cosmetic goods. The subject of the investigation is the compositional and functional structure of perfume and cosmetic names represented in naming complexes, the types of nomination occurred within the components of naming complexes.

Literature review. Perfume and cosmetic goods being in the process of naming and obtaining corresponding goods names come into the sphere of linguistic research which is mostly focused on the terminological system [8]. When the investigation of naming is restricted with the terminology brackets, it narrows the research immensely [15, p.117]. As a result, the process of individual names given to certain class goods is on the periphery of linguistic attention [14, p.901]. Associativeness of goods names is the collection of features connected with the company producer or its products which are always recollected by consumers when they hear corresponding goods names $[6, p .17]$. Name plays a significant role in gaining success in goods, company or service [5, p.175]. Any goods name is characterised by the set of features which are grouped in five classes: (1) distinctiveness, expressiveness, uniqueness; (2) representation of detailed information about goods, company, service; (3) easy for remembering and pronunciation; (4) pleasant and attractive sounding and spelling, graphic representation; (5) absence of negative 
connotation in the regional variant of language, slang, translation in case of translating into other languages [13]. Perfume and cosmetic names do not appear sporadically or unexpectedly. They are closely connected with the world of fashion which is reflected in the multibranch polyaspective nomination corpus [7, p.196]. It is reasonable to involve naming traditions of colour, objects of flora and fauna, appearance, and personal name. These traditions may influence the name formation of a wide choice of perfume and cosmetic names finding their reflection in naming structures [1, p.269]. Perfume and cosmetic names gain further attractiveness involving names of animals and flowers, transforming them into names of goods. The corpus of perfume and make-up names includes the heroes of legends and myths [4, p.71]. Fragrant and make-up are named and produced according to the gender differentiation of consumers. That is why gender differentiation finds its reflection in the naming process [9, p.164]. All personal names can be transformed into common names if they belong to celebrities. At first, popularity comes to the name-bearer (real person, literature, character, geographical place, object or phenomenon) due to their unique properties (outstanding feature, personal individuality or action). If that well-known name outlives the epoch of its bearer, it turns into a symbol due to adding the associative seme indicating a specific feature or characteristic (personal name+associative seme $=$ symbolic personal name), these names are Ford, Chanel, Tiffany [11, p.321]. Linguistic investigations underline that onomastic aspect of perfume names was not analysed, and the perfume goods names were not distinguished as a separate subgroup of goods' signs. Indirect perfume naming is believed to represent nominators' estimate activity [2, p.169-170]. Axiological perfume naming reflects nominator's desire to represent perfume goods in the best and most attractive way, underlying all possible attractive characteristics in the name [10, p.178]. Olfactory naming involves a synaesthesia metaphor with a scent component of meaning. In this case, metaphorical synaesthesia's way of representing aromatic substances is used [12, p.40]. Olfactory characteristics may be indicated with the term "scent name". It is recognized as a lexical unit to the meaning of 
which the categorical-lexical seme "smell" is indicated. Perfume naming analysis is impossible without involving the perfume market which has well-developed segmentation [3, p.67]. Globalisation and parallel processes of simplification, speeding up unification, influenced the art of perfume production. Fragrances were produced as quickly as a new fashion appeared (a few for a season). Before that acceleration new scents required a few years for their production. As a result of these processes, the production of global perfume goods was established. The social values were transformed creating megabrands and introducing new patterns of beauty [4, p.69]. Renaissance of ancient classical traditions and forgotten (partially lost) perfume recipes became the reaction on sad, plain fragrances which were represented in mass selling. The new tendencies were connected with creating provocative and unexpected aromatic compounds. Having taken creativity as the aim, this tendency in perfume production got individual naming (artistic perfumery) [4, p.70]. In the case of mass perfume products, a consumer pays a lot for expenses for marketing communication which were provided by producers. The alternative selective perfume goods require the expenses for the components of goods, the work of chemists and the opportunity of being connected with fine art $[6$, p.25]. From the marketing point of view, one phenomenon substitutes another: mass brand J'adore Dior pretends to use traditions and techniques connected with different types of goods. Selective perfumes are produced by companies and firms building their business around the personal name of a producer-manufacturer. It implies the producer's high personal responsibility and at the same time the high quality of goods [2, p.114]. High-level selective perfumers are connected with traditions and history of the fashionable brand. They have high prices and their distribution is limited. The names of brand perfumes should be comfortable for remembering, they should have contents. In particular, the name with contents may support the process of brand remembered by consumers. It may improve its initial position on the perfume market [5, p.175]. Brand name should be associated with the goods category and induce "mental image" in the consumer's imagination. The brand 
name which is the cover for perfumes functioning on the consumer market should be functional and share positive association or connotation. It should also have a stable symbolic sense. Characteristic features of brand name connected with the marketing support of necessary image should reflect specific features of the perfume product. Brand name features should represent principles of using perfumes, there should be correlations between the brand name of a certain perfume and other products of the same brand [2, p. 6667]. The wide scale of olfactory naming is realized using colours, their shades and combinations [5, p.131]. Make-up goods are accomplished with colorative characteristics. Colour naming of this goods class of products occupies the leading position. Make-up goods are characterised by certain optic parameters reflected in the corresponding names. Colouristic naming and, in particular, colouristic adjectives are involved in associative relations. It helps form the images [7, p.201]. Lexical units of colour are very attractive from the point of practical application, in particular the development of visual communication. The present-day business develops emotional feeling perception and creates new lexemes for secondary colours. It creates something individual and attractive. It stimulates verbal creativity and leads to creating two component word combinations [7, p.76]. Colour naming of make-up products informs the consumers about anticipatory decorative effect after using corresponding cosmetics. The investigation of semantic aspect in the sphere of colour naming lipstick, rouge, eyeshade demonstrates the tendency of colour spectrum verbalization involving geographical names and lexemes with abstract semantics. Colour naming is realized in a very original way concerning lipstick naming. In 2007 Deborah Merskin provided a detailed classification of brand lipstick names. Using the categorical analysis, she singled out fourteen groups. It means that ways of colour naming may be different starting with real colours and finishing with abstract categories [16].

The literature review demonstrates the absence of deep penetration into the aspect which reveals the interaction of nomination types in the sphere of perfume and cosmetic naming. The lack of information about nomination types in this sphere did not 
enable linguists to distinguish all possible types of nominations applied for naming perfume and cosmetic goods. The general tendency provided, types of nomination according to the classes of perfume and cosmetic goods were not distributed and separated. There were no definite ideas about the primary, secondary and repeated nominations applied for corresponding goods. All these informative lacunes demonstrate the necessity of their filling.

Results. The process of correlation research on the aspect of nomination types is to distinguish the initial unit of typological description. This unit is an inner form of naming. Inner form understanding as a feature of nomination is a clue in the investigation of perfume and cosmetic lexemes in naming aspect. It is explained by involving two initial facts. The most common way of nomination is naming by indicating one of the reality features which is designated. The choice of nomination feature stipulates the motivation of lexical units. Motivation is understood as a cause and effect relation between sound and sense, phonation and word meaning. Any complex linguistic unit (derivative word, compound word, word combination) is motivated as far as its meaning is motivated with the meaning of elements combined with it. Simple linguistic units may be motivated only as a result of semantic comprehension of sound imitation associations. In the corpus of perfume and cosmetic names, the motivated units are divided into complex ones according to their structure (derivative, compound words and phrases) and simple ones (their meaning is created as a result of semantic trying to understand). Motivation is recognized as morphological (the meaning of the word is originated from the meaning of its components) and semantic (the meaning of the word is formed as a result of comprehension). Among the perfume and cosmetic names there is a small group of borrowings which is the reflection of perfume and cosmetic traditions of Italy, France and Greece (Premiére, J'adore, Lunna Rossa, Capture Totale, Terre D'HERMÉS, Dahlia Noir, Mon Jasmin Noir, Omnia Coral, Nero Assoluto, Mètèorites Perles, Hypnôse Drama, La petite robe noire, Eros). Perfume and cosmetic name borrowings belong to the nonmotivated class as their structure and semantics are in the sphere of 
languages from which they were borrowed. In the case of a primary nomination, a motivation feature is designated with a word that has the basic meaning containing the indication of the motivation feature. Name meaning correlates with the reality which is denotated. It causes the direct reflection of object features. This object has conceptual language segmentation. It indicates the direct and autonomous way of understanding that extralinguistic object. In the case of a secondary nomination, the indication of the distinguished feature is realized with comparison or confrontation with another object naming the same features. Using the limited devices, language is able to fix and represent society's experience. It means that a lot of words can represent a few meanings performing the secondary semantic function. Such development of the word semantic structure takes place in the corpus of perfume and cosmetic names. These names are semantic derivatives. In the language, semantic derivatives are created as a result of trying to understand the meaning of linguistic units when the derivation of the meaning is likely to take place in the inner sphere of the word. Semantic derivatives perform a nominative determinative function. It means that derivatives nominate objects and give them characteristics simultaneously. The research applied to the perfume and cosmetic names is macrolinguistic as such understanding of the semantic components is in a complete correlation with the modern theory of nomination. In the aspect of macrolinguistic research approach to the semantic phenomenon, the semantic meaning of the word is understood as a combination of elementary sense semes where every seme is a reflection of recognitive, differential features in the linguistic consciousness of an individual. These features are connected with the denotate or associated with it under the influence of linguistic sphere. The location of semes in the word semantic structure is hierarchical and non-linear. Within the perfume and cosmetic naming corpus, there were distinguished three different semes according to the degree of hierarchy. Archsemes or integral semes reflect the features connected with the whole class of objects. Those features may be common for the thematic or lexico-thematic group. Differential or giposemes create the nucleus of the word meaning. They grasp the 
features that differ the meaning of a certain word from the semantics of the words of the same group or field. Potential semes reflect the secondary order features and associations of the object. They could be found out in certain contexts. These semes contradict the whole lexical class features. As a result of topicalization of potential semes taking place on the property of the word seme structure, semantic derivations happen. They create the relation with the basic name using invariant potential semes.

Perfume and cosmetic naming is realized within the frame of naming complex which grasps two naming components. A component functions as an individual name of perfume or make-up. A individual name as a naming unit may be formed with lexical units (euphoria, poison, passion, miracle, hypnosis, mystery, glamorous, obsession, signature) or phrases (ageless bloom, yellow diamond, lovely garden, fresh rose, purple lilac, red apple, golden gloss, ideal shade, white linen). B component functions as a goods name and $\mathbf{B}$ name as a naming unit is restricted in choice and limited within the terminology system. The perfume goods names include such terms as eau de perfum, eau de toilette, eau de cologne, mascara, eyeliner, eye shadow, lipstick, nail wear, loose powder, blush, face cream. Perfume and cosmetic naming complex grasping $\mathbf{A}$ individual and $\mathbf{B}$ goods names may be represented as a formula $\{\mathbf{A}+\mathbf{B}\}$. Functioning within one common naming complex $\mathbf{A}$ individual and $\mathbf{B}$ goods names influence each other unequally. $\mathbf{B}$ components being stable and connected with terminology system create the background for choosing and creating $\mathbf{A}$ components. B components are chosen according to goods classification and main properties (mostly substantial ones) of corresponding perfume and cosmetic goods. Nominators-producers cannot apply any $\mathbf{B}$ component as they are represented by the corresponding terminology which is admissible for certain goods. All these features of $\mathbf{B}$ component are reflected in its functional features turning this terminology system units into the corresponding semes in A component. Nominators-producers may choose any A component for any $\mathbf{B}$ component without any restrictions but there is a definite dependence of $\mathbf{A}$ component upon B component. The goods names in the sphere of perfumes and 
cosmetics are the bearers of basic features which are concentrated in B component indicating perfume and relative goods. Perfume goods creating fragrant effect have olfactory feature as their basic characteristic. It means that the combinations of scent and fragrance concentrated in aromatic solutions of different substances correspond to the essential requirements of aromatic liquid goods.

The goods in the sphere of cosmetics and make-up creating visual effect have colour and colouring as their basic characteristics. It may be used for protective colouring or painting some body parts using different paints, pigments with varied colours and shades. Therefore, the combination of different multicoloured chemicals corresponds to the essential requirements to multicoloured liquids, solids and soft powdered or creamy substances. In the process of creating $\mathbf{A}$ individual names, the nominators-producers provide their choice taking into consideration $\mathbf{B}$ goods names. There should be an explicit or implicit correspondence between features of $\mathbf{B}$ goods names and chosen $\mathbf{A}$ individual names. If the perfume and cosmetic naming complex can be schematized as $\{\mathbf{A}+\mathbf{B}\}$, the relation between $\mathbf{A}$ individual name and $\mathbf{B}$ goods name may be shown as $\{\mathbf{A} \leftarrow \mathbf{B}\}$ demonstrating the leading position of $\mathbf{B}$ name in the process of choosing A name. The details of this process are hidden in the correspondence of dictionary definitions of both $\mathbf{A}$ and $\mathbf{B}$ names. When $\mathbf{B}$ names are bearers of basic goods features, $\mathbf{A}$ names are chosen among naming units - words or phrases - if there are any individual features, which have explicit or implicit resemblance with the basic features of $\mathbf{B}$ names. This correspondence may be revealed and found in the process of comparison of dictionary definitions of $\mathbf{A}$ and $\mathbf{B}$ names. Dictionary definitions consisting of different types of semes demonstrate substantial chemical and material nature of the objects represented with $\mathbf{B}$ names and the varieties of meaning represented in $\mathbf{A}$ names. Correlations between semes of $\mathbf{A}$ and $\mathbf{B}$ names may be explicit or implicit, direct or indirect. The induction power of $\mathbf{B}$ names may change some semes in the definitions of $\mathbf{A}$ names, making them applicable for the nomination process of perfume and cosmetic goods. The process of secondary naming when perfume and cosmetic goods get $\mathbf{A}$ individual names includes four 
basic stages according to the order of occurrence they are archseme fading or suppression $\{\mathbf{A} \leftarrow \mathbf{B}\}$; seme displacement, removal and occasional seme indication $\{\mathbf{A} \leftarrow \mathbf{B}\}$; potential seme actualization $\{\mathbf{A} \leftarrow-\mathbf{B}\}$; occasional seme formation $\{\mathbf{A} \leftarrow \cdot-\cdot \mathbf{B}\}$. At the very end of these transformations, A individual is turned into a semantic derivative (SD) and it is a product of secondary nomination, giving the improved semantic structure to the naming complex [SD $\leftarrow \mathbf{A} \leftarrow \mathbf{B}\}$.

In the corpus of perfume and cosmetic names, semantic derivation has its own specification. In the base of perfume and cosmetic names created in a semantic way there are universal laws of trying to understand the word meaning and transferring one object into another. Metaphor and metonymy, which are based on the resemblance of different objects of reality, are involved here for the unification of different realities. These realities may vary but they are united under the invariant linguistic forms. The most frequent semantic derivation for creating perfume and cosmetic names is metaphorical transferring. It is based on the feature resemblance of two objects which are not connected to reality. The general feature (invariant) is the background for providing the act of semantic derivation. The invariant is distinguished on the basis of associative relations which are classified as inherent and adherent. In the perfume and cosmetic naming corpus, there are some $\mathbf{A}$ individual names which were created in the way of trying to understand the meaning that was historically formed and conventionally fixed. That meaning is a result of inherent associations. They stimulate word comprehension on the basis of real resemblance of the signified with the features which are named. Correspondingly, the base of comprehension of the usual meaning is formed along with changing the denotative correlation within the common (invariant) feature. This process involves the displacement of primary denotative correlation from the object of usual naming on the new denotate. That displacement is followed by some stages. They reflect two transformations of the seme structure of the language sign meaning. The first stage grasps the neutralization of the archseme which correlates with the usual denotate. The second stage creates the 
ground for forming the potential seme which correlates with a new denotate. When A individual name is formed as a semantic derivative, one archseme substitutes another; the common character of two meanings is determined by the invariant potential seme of meaning. The powerful naming potentials are realized in the possibility of the recurrent use of lexical units. According to the mechanism of metaphorical transferring and structural and semantic specification, all $\mathbf{A}$ individual names are divided into two basic groups. The first group contains words. These naming units have the names of objects whose resemblance is indicated and reflected (sensuelle, solutions, perceive, premiere, eros, la mer, signorina). The second group grasps naming units-phrases. The second group is divided into two subgroups according to the origin of the object name. The first subgroup contains naming units-phrases consisting of an attributive component and an object name which is compared (Montblanc Legend; color designer; man extreme; blanc expert; terre d'Hermès; Lady million; 1 million; homme sport; bright crystal; Versace crystal noir; a new platinum night; for away; slip...into; secret fantasy kiss). The second subgroup contains naming units-phrases consisting of an attributive component and an object name which has undergone comprehension process (pura blanca, rare sapphires, blooming bouquet, mon jasmin noir, cool water, acqua di parma, olive oil, hypnotic poison, Versace varitas, citrus chill, garden of Eden). The second group demonstrates the indirect representation of the attributive component in semantics which is directly focused on the object of naming. It happens within the integrated and complex perfume and cosmetic names. All investigated $\mathbf{A}$ individual names are likely to have a common integrated base which is understood as a connection of the primary and secondary nomination mechanisms. In the naming of extralinguistic objects, the mixed character of nomination is used. It means that there are component combinations with direct naming denotative characteristics. These $\mathbf{B}$ goods names-components are eau de parfum, mascara, eau de toilette, eau de cologne, cream; they are targeted at the object. Other components have comprehended attributive elements such as bright crystal, a new platinum night. 
These components are connected with the objects of cognition in an indirect way. Within A perfume individual name which is the part of naming complex (Versace Eros Eau de Toilette spray the new fragrance for men), the semantic derivative Eros adds the object of extralinguistic reality - toilet water - the feature of possessing strong magic of sexual masculine attractiveness. In this case, the potential seme topicalization is improved with the basic knowledge of nominators and recipients: Eros "mythical personage" (archseme) + "authority over love feelings" (potential seme). In the naming complex Guerlan la petite Robe noir Eau de Toilette Spray, the semantic derivative A individual name la petite Robe noir gives the extralinguistic reality to the object Toilette Spray features of elegance, refinement belonging to the world of high fashion. It is the world where Coco Chanel invented her pattern of evening dress. In this case, the topicalization of potential seme is improved with the background knowledge: "la petite Robe noir" as a pattern of evening dress which was a democratic alternative of uncomfortable and awkward variants with corsets" (archseme) + "elegance, finesse and simplicity" (potential seme). Secondary occasional nomination reflected in $\mathbf{A}$ individual names is realized on the basis of denotative correlation shifting. In this case, the transfer of the common feature from the primary nomination object to the object of secondary nomination occurs. The secondary occasional nomination mechanism includes a range of stages and transformations. If the semantics of $\mathbf{A}$ individual names is analysed, the main point is connected with the common feature which is described with the shared seme "pleasant smell". B goods name-component Eau de Toilette has A individual name "Purple Lilac" whose last name was obtained as a result of the multistage process. "Purple Lilac" is determined involving its dictionary definition "a bush or small tree with sweet-smelling purple or white flower" [17]. The next stage is connected with fading the archseme "bush, small tree", the occasional seme "eau de toilette" is formed. After that, there happens the seme displacement "bush, small tree $\rightarrow$ eau de toilette". Then the topicalization of the potential seme "sweet smell" is observed. The occasional seme forms "smell nice", which correlates with the 
dictionary definition of the goods classificatory - B goods name "eau de toilette" - "a liquid containing a small amount of perfume, used by women to make them feel fresh and smell nice" [21, p.497]. As a result of that multistage process, there happened the displacement of the primary denotative correlation on the base of transferring the common (shared) feature from the object of primary (usual) naming (in that case it is a plant "purple lilac") on the object of secondary (occasional) naming (in that case it is "eau de toilette"). The primary nomination object feature "sweet smell" becomes leading. It is added to the object of a secondary nomination. That feature creates the ground for further occasional naming. Occasional renaming is realized due to the displacement of denotative correlation, suppression of usual denotation and appearance of occasional reference. Occasional renaming is involved in nomination "eau de parfum". The object of primary naming is "orange blossom" which has a dictionary definition "the fragrant flower of the citrus sinensis (orange tree). It is used in perfume making" [20]. When the archseme "flower" is suppressed, it causes the seme displacement and after that the occasional seme "eau de parfum" is induced. After the seme redistribution, the potential seme "fragrant" is actualized. The occasional seme "fragrant or pleasing scent" is created and correlates with the dictionary definition of $\mathbf{B}$ goods name "eau de parfum" - "a substance producing a fragrant or pleasing scent; esp. a volative oil, as that extracted from flowers, or a substance like this prepared synthetically" [18]. As a result of these stages and gradual steps, the occasional seme "pleasing scent" is laminated on the actualized potential seme "fragrant".

If the B goods name of make-up group is analysed, the semantic aspect of the first position belongs to the shared feature which is described with the common seme "colour, coloration". A mascara has got its A individual name "super magnify black" after the process of occasional renaming. The seme analysis starts with the selection of the nucleus component within the phrase naming unit. The component "black" has its dictionary definition "having the darkest colour there is, like the colour of coal or a very dark night" [17]. As a result of archseme "colour of coal or a very dark night" 
fading the seme, displacement takes place and the last step is connected with the occasional seme "mascara" which is induced at the very end. After the seme redistribution, the potential seme "dark" is actualized. Simultaneously, the occasional seme "dark" is formed. It correlates with the dictionary definition of B "mascara" - "a thick dark liquid of make-up that is used to make eyelashes darker, make them appear thicker and longer" [17]. These stages lead to the stratification and coincidence of actualized potential and occasional seme "dark". B lipstick that has its A individual name "Red Apple" has got its name as a result of multistage process. A "red apple" is defined using the stratification of two dictionary definitions. They reveal this phrase naming unit in semantics: "red - having the colour of blood [19]; apple - a round fruit with firm white flesh and a green, red or yellow skin" [17]. The initial stage starts with fading the archseme "fruit". The occasional seme "lipstick" is formed. There takes place the removal of semes "fruit" $\rightarrow$ "lipstick". The occasional seme "colour" is formed and it correlates with the dictionary definition of B "lipstick" - "something used for adding colour to your lips, in the shape of a small stick" [19]. The feature of the primary naming object "red" becomes leading and is added to the object of secondary naming underlining the fact that the lipstick has the red apple colour. B "lip gloss" has A individual name "pink" and this name was given to it after the process of occasional renaming. The seme analysis starts with the naming-word "pink". It has the dictionary definition: "of a pale red colour" [17]. When the archseme "red" is suppressed and removed, the occasional seme "lip gloss" is reduced. After the redistribution, the potential seme "pale colour" is actualized. The occasional seme "very shiny" is formed. It correlates with the dictionary definition of B "lip gloss" - "a substance used to make lips look very shiny" [21, p. 943]. In the case of semantic analysis of the cosmetic, nourishing cream, in particular, its $\mathbf{A}$ individual name, the leading position belongs to the tactile characteristics of these substances (softness, tenderness). Nourishing cream has its A individual name "gentle peeling" which appeared as a result of multistage process. Within the naming phrase, the leading 
role belongs to the attributive "gentle" having dictionary definition; "kind, calm or soft" [17]. The initial phrase starts with fading archsemes "calm, kind". The occasional seme "cream" is created. The following phrase is connected with creating the potential seme "soft". It coincides with the created occasional seme "soft substance" that correlates with the dictionary definition of $\mathbf{B}$ cream: "a soft substance that you rub into your skin" [17]. If the phenomenon of synaesthesia is involved in the process of occasional renaming, the common (shared) feature that enables the removal of denotative correlation is determined in an indirect way. In the case when tactile feelings are used for representing smell, the rhetorical transferring occurs. B perfume has A individual name "Cashmere Mis". In this naming unit-phrase the leading position belongs to the attributive cashmere with the dictionary definition "a type of fine soft wool" [19]; very soft expensive wool material that is made from the hair of goat from Kashmir" [17]. The archseme "wool material" is suppressed and the occasional seme "perfume" is induced. The potential seme "expensive" is actualized instead of the potential seme "very soft". Simultaneously, in the dictionary definition of B goods name "perfume often indicates a strong and rich smell" [24], the potential seme "rich" is actualized. There happens the stratification of two semes "expensive" and "rich". Dictionary definition of these two semes ("expensive" - "costing a lot of money" [21, p. 547]; "rich" - "someone who is rich, has a lot of money and valuable possession" [21, p. 1413]) helps understand that in the perfume name the occasional seme is created. That seme underlines the specification of scent and its correlation with the price "rich", "expensive smell". In this way, the olfactory perfume properties are characterised when the secondary order seme is actualized instead of the actualization of primary order one. Metaphorical transferring is used when the olfactory characteristic is represented involving psychoemotional feelings. B perfume has $\mathbf{A}$ individual name "passion". This naming unit-word has a dictionary definition " $a$ strong feeling of love or enthusiasm, especially in the context of a sexual relationship; a very powerful feeling, for example, of sexual 
attraction, love, hate, anger or other emotions" [25]. Later there happens the suppression of archseme "feeling, emotion" and the potential seme "perfume" is formed. In the dictionary definition of $\mathbf{B}$ name ("perfume often indicates a strong, rich smell" [24]), the potential seme "strong" is actualized. The last step is connected with the stratification of two semes ("strong" - "having a taste or smell that you notice easily" [21, p.1864]; "powerful - "having a lot of power or influence" [21, p.1648]). Dictionary definitions of two semes ("powerful", "strong") help understand that there is a process of occasional seme creation in the perfume names and that seme reveals the specification of "strong smell". This is the way of characterizing olfactory specification of perfumes. That feature is reflected in A individual name. Metaphorical transferring takes place when visual feelings are involved in naming the olfactory properties. Perfume has A individual name "red" and that naming unit (word) has its dictionary definition: "having the colour of fresh blood" [17]. The archseme "colour" is faded and the occasional seme "perfume" is formed. The potential seme "fresh" is actualized. The potential seme "fresh smell" is actualized in the dictionary definition of $\mathbf{B}$ goods name ("perfume often indicates a strong, rich smell", "fragrance is usually applied to a sweet, delicate and fresh smell" [24]). The dictionary definition of lexical unit "fresh" - "taste/smell etc. [usually before noun], pleasantly clear or cool" [21, p.644] confirms that the occasional seme in $\mathbf{A}$ individual perfume name is formed. This seme reveals the specification of scent "fresh smell". In this way perfume olfactory features are estimated and reflected in $\mathbf{A}$ individual name. Metaphorical transferring takes place when visual feelings are represented using emotional component. B mascara had A individual name "irresistible sexy". This naming unit-phrase is defined with the following dictionary definitions: "irresistible" "impossible to refuse, oppose or avoid because it is too pleasant, attractive or strong" [17]; "too attractive and tempting to be resisted" [17]; "sexy" - "attractive or exciting" [23]. Here again the suppression of archseme "sexy" occurs and the occasional seme "mascara" is created. The potential seme "attractive" is actualized. 
The potential seme "colour" is actualized in the dictionary definition of B name "mascara" - "a dark substance used to colour your eyelashes and make them look thicker" [19]. The dictionary definition of lexical unit "colour" ("the appearance of something as a result of the way it reflects light, especially when its appearance is very bright or is made up of a lot of different colours" [21, p. 295]) confirms that the occasional seme is created in $\mathbf{A}$ individual name "mascara", and this seme reveals the optic characteristic of this substance "attractive colour". In this way optic features are represented obtaining certain appreciation within $\mathbf{A}$ individual name. Metaphorical transferring takes place when the tactile feelings are used for describing a visual feeling. B face powder had its $\mathbf{A}$ individual name "Velvety". This naming unit-word has its dictionary definition "having the character of velvety as in being soft, smooth, thick or richly hued" [22]. The archseme "velvet" is faded and the occasional seme "face powder" is formed. The potential seme "soft" is actualized. Simultaneously, the potential seme "coloured" is actualized in the dictionary definition of $\mathbf{B}$ goods name "face powder" - "a skin-coloured powder used on the face to make it look less shiny and more attractive" [17]. The combination of two semes "soft" and "colour" is reflected in the dictionary definition "soft colours or light are pleasant and relaxing because they are not too bright" [21, p. 1572], but semes "smooth", "thick" are not connected with the seme "colour". In this way the colour naming of "face powder" is realized when the seme "soft" is actualized, which simultaneously correlates with visual and tactile properties. The occasional renaming process may create the wrong impression on the recipient creating an illusion of involving the phenomenon of synaesthesia. B nourishing cream has A individual name "Organic Vanilla". The dictionary definition of the nucleus component of that naming unit-phrase is "a substance obtained from vanilla pods or produced artificially and used to flavor foods or to import a fragrant scent to cosmetic preparations" [19]. The dictionary definition of B goods name "cream" ("a soft solid or thick liquid containing medicaments or other specific ingredients applied externally for a 
prophylactic, therapeutic or cosmetic purpose" [18]) confirms that seme "soft" is leading in the definition of that cosmetic substance. This tactile characteristic is stable, constant, unchangeable and it exists independently from $\mathbf{A}$ individual name which nominates the cosmetic goods not in the aspect of its main leading feature "soft" but in an indirect way, underlying the olfactory feature "fragrant scent". There takes place an independent coexistence of two naming components in the naming frame. B goods name "cream" indicates the goods classification and its main feature "soft" is given a priority. A individual name nominates the cosmetic goods, moving to the first position of fragrant characteristics. In this case, the phenomenon of synaesthesia is not involved into the naming process.

Conclusion. The semantic structure of $\mathbf{A}$ individual names in naming frames is the reflection of the relation existing between objects of extralinguistic reality. It also reflects the results of a person's cognitive activity. The person is a member of the language community who has the reflection of reality with all its specification. A individual name was found to be the leading component which describes the characteristics of a nominated perfume and cosmetic goods. A individual name is a result and reflection of some types of nominations, the leading is repeated and secondary nominations occur. A individual name is a semantic derivative which is formed involving metaphorical transferring or comprehension. All these phenomena confirm the process of the name functional adaptation. It means that the gradual transition from the primary to the secondary nomination takes place. The object of nomination is changed; metaphorical transferring and trying to understand occur simultaneously. Functional adaptation is the realization of a nameproducer's desire to get a high-profit margin in the process of selling perfume and cosmetic goods.

\section{REFERENCES}

1. Algeo, J., Algeo, K. (2000). Onomastics as an Interdisciplinary Study. Names, 148 (3/4), 265-274 [in English].

2. Anholt, S. (2003). Brand New Justice: the upside of global branding. Oxford: Butterworth Heinemann, 272 p. [in English]. 
3. Brinker, K. (2011). Linguistic Textanalysis [Linguistische Textanalyse]. Berlin: Erich Schmidt, 384 S. [in German]

4. Briot, E. (2007). Fashion Sprayed and Displayed: The Market for Re-parfumery in Nineteenth-Century Paris. Proceedings of the Economic History Society Annual Conference: Exeter: University of Exeter, 69-72 [in English].

5. Chernatony, L., de Mc.Donald, M., Wallance, E. (2011). Creating Powerful Brands. New York: Taylor and Francis, 268 p. [in English].

6. Doxit, S. (2009). Fine Fragrance Business Trends. Chemical Business, 23 (6), 11-26 [in English].

7. Fauconnier, G., Turner, M. (2002). The way we think: conceptual blending and the Mid's Hidden Complexities: New York: Basic Books, 298 p. [in English].

8. Felber, M. (2002). Terminology Manual: Paris: UNESCO, Inform, 426 p. [in English].

9. Frisson, S., Pickering, M. (2007). Obtaining a figurative interpretation of a word: support for underspecification. Metaphor and Symbol, 16, 149-174. [in English].

10. Geeraers, D. (2010). Theories of lexical semantics. Oxford: Oxford University Press. 341 p. [in English].

11. Gibbs, Raymend, W. (2001). Evaluating contemporary models of figurative language understanding. Metaphor and Symbol, 16, 317-333. [in English].

12. Grossenbachen, P.G., Lovelce, C.T. (2001). Mechanisms of synaesthesia: cognitive and psychological contains. Trends cognitive science, 1(15), 36-41. [in English].

13. Habibi, R. (2011). Pragmatic naming of onyms. $I V$-th International Conference on Pragmalinguistics and Speech Practice. Newcastle upon Tyne: Cambridge Scholars Publishing, 215-217. [in English].

14. Jones, G. (2011). Globalization and Beauty: A Historical and Firm Perspective. EUROAMERICA, 41(4), 885-916. [in English].

15. Kohli, C., Suri, R. (2000). Brand Names that work: A study of the Effectiveness of Different Types of Brand Names. Marketing Management Journal, 10(2), 112-120. [in English].

16. Merskin, D. (2007). Truly Toffee and Raisin Hell: A Textual Analysis of Lipstick Names. Sex Roles, 56, 891-900 [in English]. 


\section{DICTIONARIES}

17. Cambridge English Dictionary. URL: https://dictionary.cambridge.org/

18. Collins English Dictionary. URL: https://www.collinsdictionary.com/

19. Longman dictionary. URL: https://www.ldoceonline.com/

20. English Wikipedia. URL: https://en.wikipedia.org/wiki/English_ Wikipedia

21. Longman Dictionary of Contemporary English (2006). Harlow: Pearson Education Limited. 1951 p.

22. Meriam-Webster Dictionary. URL: https://www.merriamwebster.com/
23. Oxford
Learner's
Dictionary.
URL: https://www.oxfordlearnersdictionaries.com/

24. Random House Webster's College Dictionary (2005). Random House Reference: Indexed edition. 1632 p.

25. Webster's New World College Dictionary. URL: https://www.yourdictionary.com/about/websters-new-world-collegedictionary.html 